\title{
The mysteries of Blaise Pascal's sutures
}

\author{
Marc Zanello • Eric Arnaud • Federico Di Rocco
}

Received: 19 December 2014 / Accepted: 2 February 2015 / Published online: 20 February 2015

(C) Springer-Verlag Berlin Heidelberg 2015

\section{Introduction}

Blaise Pascal was born on 19 June 1623 at Clermont-Ferrand (France). Blaise Pascal had two sisters, Jacqueline and Gilberte. He lost his mother when he was 3 years old and was exclusively educated by his father, Etienne Pascal, a cultivated tax collector. In 1631, a promotion for Etienne Pascal allowed the Pascal family to move to Paris (France). Quickly, the young Blaise Pascal showed some great abilities and found naturally his place in the Academy, ancestor of the French Academy of Sciences. When he was only 11 years old, Blaise Pascal wrote his first scientific book, the Traité des sons [1]. Due to the opposition of Etienne Pascal against Cardinal Richelieu's economic policy, the Pascal family had to run away from Paris in 1638. Jacqueline Pascal, another child prodigy, helped the return to favor of his father, and in 1640, Etienne Pascal settled down in Rouen as superintendent of Normandy. Blaise Pascal continued to work on geometry and on his calculator finished in 1642. The most important event of their stay in Rouen was their conversion to Jansenism, a Christian theological movement emphasizing original sin and the necessity of the divine grace for predestinated persons. The Pascal family came back to Paris in 1648. On 19 September 1648, Blaise Pascal, also interested in physics,

M. Zanello $(\bowtie) \cdot$ E. Arnaud $\cdot$ F. Di Rocco

Department of Pediatric Neurosurgery, Necker Children's Hospital, 149 Rue de Sèvres, 75015 Paris, France

e-mail: marc.zanello@orange.fr

M. Zanello • E. Arnaud · F. Di Rocco

Paris Descartes University, Paris, France made his famous experiment on vacuum published in Récit de la grande expérience de l'équilibre des liqueurs [2]. Etienne Pascal died on September 24, 1651. Due to their conversion, Blaise and Jacqueline Pascal became close to the Jansenists of Port-Royal-des-Champs. In 1654, he resolved several mathematical problems creating the bases of probability and the integral calculus. During the night between 23 and 24 November 1654, he experienced a mystical experience. Combined with retreats made in 1655 and 1656, Blaise Pascal asserted his religious beliefs: he was the author of a series of the 18 Lettres Provinciales [3]. In these letters, Blaise Pascal defended the Jansenist Antoine Arnauld from Port-Royaldes-Champs and criticized the laxity of Jesuits. His faith was strengthened by the miraculous recovery of one of his nieces on the 24 March 1656. Blaise Pascal worked on pedagogic, scientific, religious, and literary projects. For example, at the beginning of 1662, he managed one of the first public transportations ever invented. It was only in 1669 , posthumously, that Les Pensées was published [4]. This masterpiece is considered as one of the most important texts of the French language today [1].

Blaise Pascal had poor health throughout his life. But, it was after his majority that his condition degraded. His sister Gilberte wrote: "From the age of 18, he would not have spent 1 day without pain" [5]. A headache was the principal symptom of his disease [6].

More than 65 references were found concerning his illness and his death [7]. None of the proposed diagnoses is satisfactory.

The objective of this work is to have a scientific review of this French genius' life in order to give a more accurate diagnosis. 


\section{Life, death, and autopsy of Blaise Pascal}

Despite his numerous writings, Blaise Pascal was discreet concerning his own life. It was only in his letter to Pierre Fermat, dated from August 1660, that we could find a citation regarding his disease: "he is so weak that he cannot walk without a stick" [6]. We had to refer to the vague words of his sister Gilberte: "since his 18 , he would not have a day without pain; at 24 years old they had increased a lot; he could not drink anything, an unbearable headache, an excessive heat of entrails and many other troubles" [5]. Blaise Pascal's only long-term treatment was laxative to cure an abdominal disorder badly described [1]. This sort of medical treatment was quite common in the 17 th century.

We had to quote a letter of the Boileau monk, dated from 1737: Blaise Pascal had "an abime on his left side" and "difficult [for him] to move and talk especially during the morning" [6]. Moreover, a French thesis, focused on the disease of Blaise Pascal, noted a hemianopsic margin in some of his works, suggesting a chronic visual impairment [8].

On 2 July 1662, Blaise Pascal presented abdominal pain, still treated by a combination of laxative potions and emetic agents. His condition continued to degrade with major asthenia, loss of weight, and anorexia. On 14 August 1662, painful headaches appeared brutally. During the night between the 17 and 18 August following an increase of his headaches, he had a generalized epileptic seizure followed by status epilepticus. Blaise Pascal died 19 August 1662 [1].

This rather precocious death led to an autopsy performed on 21 August 1662 by Doctor Vallant with his assistants. His description reached us thanks to his sister Gilberte [5].

"His friends having made open his body, we found the stomach and the liver withered and intestines gangrenous, without anyone being able to judge precisely whether it had been the cause of this terrible colic that he suffered for a month, or if it had been the effect.

At the opening of the head, the skull appeared to have no suture, if it is not maybe the lambdoid or the sagittal, what apparently had caused him major headaches to which he had been subject all his life. It is true that he had formerly the suture which we call fontanel ["fontale"], but as it remained open a very long time during his childhood, as often happens at this age, and it had not been able to close, a callus was formed that had completely covered and which was so large that it could easily be felt by a finger. For the coronal suture, there was no vestige.

The doctors observed that having a prodigious quantity of brains there, the substance of which was very solid and hardly condensed, this was the reason why ["fontale"] fontanel not having been able to close, the nature had provided by a callus.

But what we noticed of more considerable and to what we attributed particularly Mister Pascal's death and past accidents that accompanied it, there were inside the skull, towards ventricles of the brain, two impressions like a finger in some wax, and these cavities were full of a curd and corrupt blood, which had begun to gangrene the Dura mater."

In the 17th century, it was quite common to make a funeral mask for persons not painted during their life. A funeral mask was made for Blaise Pascal (Fig. 1 and cover figure).

He was buried in the church of Saint Etienne du Mont in Paris where his tomb can still be seen.

\section{Discussion}

More than 65 diagnoses have already been proposed [7]. However, most of these diagnoses dated from the beginning of the 20th century, and the authors focused on the part of the autopsy describing the cerebral hemorrhage. In this series, four diagnoses came out frequently.

In first place, tuberculosis seemed probable regarding the historical context and great variety of possible symptoms. Tuberculosis of the central nervous system consists often in meningitis, and it could not explain the skull pathology [9].

Lead, mercury, antimony, or arsenic poisoning was also a common proposed diagnosis [7]. Chronic intake of heavy metal lead to symptoms like irritability or loss of memory; never seen for Blaise Pascal [10, 11].

Finally, more complex pathologies like renal polycystosis with two cerebral aneurysms or tumors with a vascular component were quoted [8]. If we ignore the chronicity of Blaise Pascal's illness, the presence of two symmetrical aneurysms in autosomal dominant polycystic kidney disease is a very rare condition [12] like simultaneous multiple intracerebral hemorrhages even in the case of hypertension $(<1 \%)$ [13].

\section{Our diagnosis}

A medical lecture of the life and autopsy of Blaise Pascal was performed to propose a new diagnosis.

The rare indications on his chronic symptoms put on light painful headaches, abdominal, and visual impairments [6]. This classical triad is associated with cranial hypertension.

The autopsy was, of course, more instructive about the etiology of his disease. We could distinguish two parts in this text: the first one described the abdominal putrefaction that followed every death, here favored by time -2 days - and hot weather. The second one suggested strongly a premature ossification of cranial sutures. It is the definition of craniosynostosis.

Craniosynostosis is a craniofacial malformation in which one or more sutures of the cranial vault are fused prematurely. Three subcategories have been introduced: simple/complex, primary/secondary, and nonsyndromic/syndromic. In simple craniosynostosis, only one suture is involved, contrary to 
Fig. 1 Blaise Pascal's death mask, Library of the Port-Royal Society, Paris (cover figure). a Front view of Blaise Pascal's death mask. b Lateral view. Note the reduced fronto-nasal angle

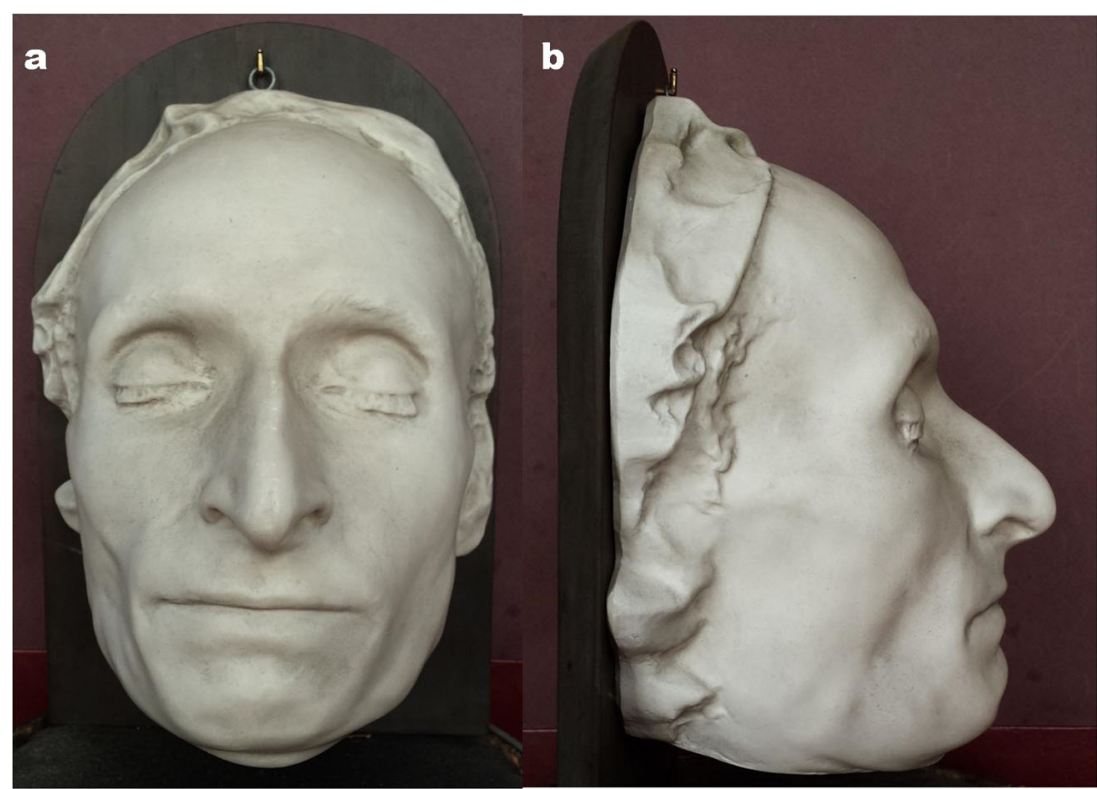

complex craniosynostosis with two or more sutures closed. Primary craniosynostosis occurs in isolation. Secondary craniosynostosis is in relation with another disorder (thalassemia, rickets, etc.). Finally, craniosynostosis can be non-syndromic or syndromic. In non-syndromic craniosynostosis, there are no other abnormalities, whereas in syndromic craniosynostosis, other body and system (cardiac, etc.) malformations exist. One craniosynostosis is observed in 2000-3000 live births. A genetic basis for craniosynostosis has been demonstrated in some patients, but in the majority of non-syndromic craniosynostosis, no specific gene mutations have been identified [14].

Which type of craniosynostosis did Blaise Pascal present?

Oxycephaly, oxus means pointed in greek, is a deformation of the vault of the skull in which the frontal and parietal regions are from the bottom up excessively sloping posteriorly and internally [15]. Coronal sutures are closed in oxycephaly: "For the coronal suture, there was no vestige." This "pointed head" ends in the "clown's hat" found at the site of the ossified bulging bregmatic fontanel [16]. Blaise Pascal's autopsy described such a "clown's hat": "It is true that he had formerly the suture which we call fontanel ["fontale"], [...], a callus had formed that had completely covered and which was so large that it could be easily felt by the finger." Oxycephaly is often diagnosed lately due to harmonious morphology and, perhaps, postnatal suture closure $[15,16]$.

Another argument in favor of oxycephaly is analysis of Blaise Pascal's funeral mask. The absence of fronto-nasal angle is a classic sign of oxycephaly [16].

Simple closure of coronal suture without involvement of any other suture can result in brachycephaly: "the skull appeared to have no suture, if it is not maybe the lambdoid or the sagittal." However, brachycephaly leads to a major cranial deformation, not seen in any portrait of Blaise Pascal [14].

Genetic proofs do not exist, but Blaise Pascal presented a quite normal face and no other pathology was noticed in his family, so it was most probably a non-syndromic craniosynostosis.

Distinction between primary and secondary craniosynostosis can be hard. Rickets can be one explanation of the higher prevalence of oxycephaly in North Africa [15]. It was a common pathology in the 17 th century, but Blaise Pascal did not present symptoms of rickets $[17,18]$. It was probably a primary craniosysnostosis.

Blaise Pascal suffered probably from a primary nonsyndromic oxycephaly.

\section{Conclusion}

Blaise Pascal, one of the greatest French minds of all time, probably suffered from oxycephaly. This craniosynostosis could explain his chronic symptoms because of a raised intracranial pressure.

Acknowledgments Valérie Guittienne-Murger and Fabien Vandermarcq of the Library of the Port-Royal Society, Paris.

Conflict of interest All authors certify that they have no affiliations with or involvement in any organization or entity with any financial interest (such as honoraria, educational grants, participation in speakers' bureaus, membership, employment, consultancies, stock ownership, or other equity interes, and expert testimony or patent-licensing arrangements), or non-financial interest (such as personal or professional relationships, affiliations, knowledge, or beliefs) in the subject matter or materials discussed in this manuscript. 


\section{References}

1. Attali J (2002) Blaise Pascal ou le génie français. Le Livre de Poche, Paris

2. Pascal B (1648) Récit de la grande expérience de l'équilibre des liqueurs, projectée par le sieur B. P. [Blaise Pascal] pour l'accomplissement du traicté qu'il a promis dans son abbrégé touchant le vuide, et faite par le sieur F. P. [Florent Perier] en une des plus hautes montagnes d'Auvergne. C. Savreux, Paris

3. Pascal B (1657) Les Provinciales, ou les Lettres escrites par Louis de Montalte à un provincial de ses amis et aux RR. PP. jésuites, sur le sujet de la morale et de la politique de ces Pères. chés Pierre de La Vallée (A Cologne)

4. Mesnard J (1992) Pascal, oeuvres complètes. Desclée de Brouwer, Paris

5. Périer G (2013) La vie de Monsieur Pascal. L'Herne

6. Mesnard J (1992) Consultations et ordonnances relatives à la dernière maladie de Pascal. Pascal oeuvres complètes T IVOeuvres divers. 1657-1662. Desclée de Brouwer, Paris, pp 1460-1503

7. Le Guern M (2010) La maladie de Pascal en 1647. Hist Sci Médicales XLIV:11-15

8. Dordain M, Dailly R (1978) Maladie et mort de Blaise Pascal, hypothèses nouvelles. impr. Lecerf, Rouen

9. Bathla G, Khandelwal G, Maller D et al (2011) Manifestations of cerebral tuberculosis. Singap Med Assoc 52:124-131
10. Graeme KA, Pollack CV (1998) Heavy metal toxicity, part II: lead and metal fume fever. J Emerg Med 16:171-177

11. Graeme KA, Pollack CV (1998) Heavy metal toxicity, part I: arsenic and mercury. J Emerg Med 16:45-56

12. Neumann HPH, Malinoc A, Bacher J et al (2012) Characteristics of intracranial aneurysms in the else krönerfresenius registry of autosomal dominant polycystic kidney disease. Cerebrovasc Dis Extra 2:71-79. doi:10.1159/ 000342620

13. Yen CP, Lin CL, Kwan AL et al (2005) Simultaneous multiple hypertensive intracerebral haemorrhages. Acta Neurochir (Wien) 147: 393-399. doi:10.1007/s00701-004-0433-y

14. Ursitti F, Fadda T, Papetti L et al (2011) Evaluation and management of nonsyndromic craniosynostosis. Acta Paediatr 100:1185-1194. doi:10.1111/j.1651-2227.2011.02299.x

15. Renier D, Cinalli G, Lajeunie E et al (1997) L'oxycephalie, une craniostenose severe. A propos d'une serie de 129 cas. Arch Pédiatriques 4:722-729

16. Vinchon M, Pellerin P, Baroncini M et al (2012) Non-syndromic oxycephaly and brachycephaly: a review. Childs Nerv Syst 28: 1439-1446. doi:10.1007/s00381-012-1800-2

17. Shore RM, Chesney RW (2013) Rickets: part I. Pediatr Radiol 43: 140-151. doi:10.1007/s00247-012-2532-x

18. Shore RM, Chesney RW (2013) Rickets: part II. Pediatr Radiol 43: 152-172. doi:10.1007/s00247-012-2536-6 